\title{
Bimal K. Matilal's Philosophy: Language, Realism, Dharma, and Ineffability
}

\section{Purushottama Bilimoria}

University of Melbourne, School of Historical and Philosophical Studies, Faculty of Arts, West Wing, Arts West (Building 148B), Victoria, Australia, 3010 , RUDN University, 6, Miklukho-Maklaya St., 117198, Moscow, Russian Federation, p.bilimoria@unimelb.edu.au

\begin{abstract}
The article considers the theoretical and practical consequences of the so-called "soft" version of epistemological realism in Bimal K. Matilal's philosophical project. The author offers an analytical view on Matilal's philosophy, which helps to understand it in a broader prospective, comparing his arguments on perception and objectivity with contemporary arguments in Western analytical philosophy; in fact, it is possible to view Matilal not only as the proponent of revised Nyāya-Vaiśeșika approach, but also as the follower of realistic view on language, following L. Wittgenstein, W. Quine, H. Putnam and M. Dummett. Despite the fact that such interpretation may sound diverse or multivocal, it nevertheless helps to better understand both lineages of argumentation: the critical review of the impossibility of private language can be compared in both Western and Indian philosophical discourses, which leads into the domain of social epistemology. The second part of the article discusses the ethical arguments on the vulnerability of moral virtues, and the place of Dharma as a term in moral philosophy. Poetical and metaphorical language appears to be a fruitful strategy to discover the ineffable - and also via negativa and catuskoti - which is shown by Matilal on the example of the unacceptability of lying. The ethical ineffability and its interconnection with Matilal's commentaries on practical wisdom play the crucial part in the interpretations of Dharmaśāstra texts.
\end{abstract}

Keywords: Bimal K. Matilal, Indian logic, Nyāya-realism, dharma, moral dilemma, theodicy, evil and ineffability doctrine

Funding and Acknowledgement of Sources. The paper is realised in the frames of the Agreement between Ministry of Science and Higher Education of the Russian Federation and Peoples' Friendship University of Russia № 075-15-2021-603 "Development of the new methodology and intellectual base for the new-generation research of Indian philosophy in correlation with the main World Philosophical Traditions».

\section{Article history:}

The article was submitted on 15.12.2020

The article was accepted on 20.01.2021

(C) Bilimoria P., 2021

(i) This work is licensed under a Creative Commons Attribution 4.0 International License https://creativecommons.org/licenses/by/4.0/ 
For citation: Bilimoria P. Bimal K. Matilal's Philosophy: Language, Realism, Dharma, and Ineffability. RUDN Journal of Philosophy. 2021;25(2):250 - 259. DOI: 10.22363/2313-23022021-25-2-250-259

\section{Introduction}

It is something of a truism and also much clichéd that Bimal K. Matilal was one of $20^{\text {th }}$ century's leading exponent of Indian logic and epistemology as well as something of an analytical visionary on the role of philosophy in classical Indian society. A special issue of Sophia was dedicated to mark the $25^{\text {th }}$ anniversary of Professor Matilal's demise and therein [1] one will also find a number of full-blown articles discussing and analysing his views and theories on a number of related issues and topics covered in the American Philosophical Association's Asian Philosophy Newsletter's special issue On Bimal Matilal [2].

Matilal took as part of his intellectual mission the correction of Western perceptions of Indian philosophy, the advancement of attention to classical and modern Indian philosophy and an examination of the confluence of currents of thought that had informed recent Indian philosophers. His philosophy drew on grammatical literature, the epics, dharmaśāstras, medical literature, poetics and literary criticism [2; 3]. One of his last works - on 'Moral Dilemmas: Insights from Indian Epics', (2000) [4] - sought to uncover the dynamic moral theorising implicit in the epics, The Rāmāyaña and The Mahābhärata.

Matilal's anekāntavāda approach to philosophy was inspired by deep intellectual commitments. He believed that a comprehensive study of literature is necessary in order to understand the dynamics of a culture's intellectual development and its fundamental philosophical commitments. He also believed deeply that philosophical cultures could neither be understood ahistorically nor in isolation from one another. Prior to Matilal's influence, Indian philosophy had been most often misconstrued in the West as being predominantly spiritual, mystical and intuitive [2]. Matilal, undermined this Orientalist prejudice by systematically developing a rigorous dialogue between European and Indian philosophy drawing both on classical and modern literature. But there is another prejudice that one has to countenance in our modern time: As Matilal explains in the lengthy introduction $[5 ; 6]$, the purpose of the first part is to dispel some of the long-ingrained impressions in the West that Indian philosophy is 'soft', it lacks a proper method of philosophising, that there is little of the critical and analytical concerns that we find in modern Western philosophy. He believed that by relating current thinking to tradition, new insights could be developed from the epistemés of the indigenous systems and that contemporary reflection could lead us to a deeper understanding of those classical systems. An example of this is his own magnum opus on Perception [6]; other examples are the epistemology of Testimony, where the extensive Indian discussions have a real prospect of informing contemporary debates. A co-edited book, Knowing From Words [7], and writings of his students on Śabdapramaña [8] are impressive illustrations of the sort of philosophical 'interconnecting' Matilal worked to provide. 


\section{Language, the Objective and Realism}

I would like to draw here from his seminal work, Perception (1985) [6]. Here Matilal presents a defence of what he called direct realism, which might also go under the name of common-sense or naïve realism, although as has been argued by J.N. Mohanty Matilal modified the Nyāya realism in its dialogue with Buddhist phenomenalism, idealism and constructionism [10]. What essentially Matilal does is establish a 'causal route from intentional objects back to material bodies; arguing the thesis that the object of sensory awareness is both an intentional object and material object.' [Ibid.] This is his new theory of objectiveness [8. P. 236-237]. What this means is that the distinct domain of percept (älambana) becomes otiose [9]. Entities that are the preserve of the 'inner circle' of ontology, are distinguished from entities posited for analysis of cognition [10]. In this way Matilal is said to have modified Navya-Nyāya ontology and presented a revisionist theory of Nyāya realism. The outstanding feature of the book is in the analysis it presents of the notion of perception in the context, again, of the realist-phenomenalist-idealist debate. Does an account of perception presuppose view of reality, or does an account of perception make possible a view of reality? Of course, this doublepronged question arises from the more simple-minded assumption in the so-called common-sense experience, that because I write on a paper that I see in front of me the sheet of paper must be there independently of my mind. But should we be surprised if through different philosophical routes this seemingly uncritical and naive attitude is actually strengthened and, for some, vindicated? Thus, what was once dubbed 'naïve realism' is nowadays called 'direct realism', but the theoretical models of perception that are proposed or developed in support of this realism have also straddled between representationalism and some form of phenomenalism [11]. But how do we move towards establishing or constructing a theory out of what Strawson calls 'our ordinary perceptual judgements'? Arguments and counterarguments from illusion, perceptual errors, doubts, fictions, imaginations and indecisions in perceptual judgements are brought in in the attempt to rebut the theories established [6]. And not a trick is missed. If perceiving is seeing, do we see substances or properties or property-instantiations? Do we see wholes or parts (are they also distinct)? The first step is to rebut the view that perception, or all instances of perceptual awareness, involve(s) inference.

Nyāya argues that our sensory awareness is direct and immediate, even if we are presented with only a part of the propertied object [11]. But since there can be no parts without whole, awareness of the 'whole' is presupposed or is a condition for the awareness of the parts. Thus, Nyāya dispenses with the need to establish a causal relation between the object and the citta-vrtti or 'mental modification'; the latter is perhaps a better description of the 'internal states' such as pleasure and pain, which need to be kept distinct from 'external' states of awareness. But the sort of immediacy that the Nyāya account argues for is a far cry from the immediacy that some representationalist theories do by reworking the old 'sense-datum' theory, the revamped sense-datum theory attempts to argue that, say, in the case of seeing, visual sense-data, such as a 'coloured shape' precedes seeing something, and that it is often in virtue of 'seeing' the coloured shape that the object is seen [11]. 
From the Nyāya perspective, it is argued that seeing the 'coloured shape' (though sometimes only a blurred patch) is not immediate; rather the converse seems to be the case, that is, one sees the tomato as having a red-shape. It should be pointed out however that the thesis regarding the directness of the percept (prakāra) as conforming to the propertied object (vișaya-viśeșana) is a development only in later (Navya-) Nyāya; the earlier school of Gautama did maintain a distinction between the mediate and immediate in perceptual awareness, only that it attributed the mediate to the penetration of conceptual and verbal elements into the minimal self-bracketed episode [12]. But while Nyāya views the process of concept-utilisation as the fulfilling conditions of a well-formed perception (we are reminded here of the Kantian principle of concept-intuition, interdependency [13]), the Buddhist Dinnāga finds this conceptual intrusion a veritable product of our constructive faculty, and that is at the root of our misconception of the real nature of things, which remains forever elusive [11]!

\section{Language and Knowledge}

Matilal was a proponent of the close relationship that exists between language and knowledge, meaning that language is intimately implicated in the construction of knowledge qua knowledge (which is not the same as the view that language essentially constructs knowledge, reductively so) [6].

In a longer paper titled Bimal Matilal's Navya-Realism, Buddhist 'Lingo-Phobia' and Mental Things I take Bimal Matilal's work to be central to the issue concerning the relationship between cognition, language and the world [14]. While developing his approach, Matilal brought many of the issues and viewpoints which were pertinent to the basic theme. It remains a comprehensive approach to the subject. Essentially, Matilal adopted the Nyāya-Vaiśeșika approach which assumes a realist perspective of the relationship between language and the world. Through this perspective he seeks to construct a realist metaphysics supported by a theory of language appropriate to it. If this realist account goes through and the analysis is accepted then according to Matilal the Buddhist critique of language is unacceptable and may be deemed as being 'lingophobic'.

I present an analytic account of how Matilal develops this realist theory of language within the Nyāya and Navya-Nyāya framework drawing also on the work of Michael Dummett and Hilary Putnam (only just as Putnam changed his view a number of times and veered closer to qualified anti-realism or 'relative realism' toward the end of his life); here the issue of language mainly arises while pinning down the structure of jñana or cognition. Cognition is always cognition of something, i.e. directed towards an object and is always expressed through some verbal form. There is an influential view in Indian epistemology which suggests that cognition necessarily consists of a sensory core required for the construction of particulars. Such a perspective denies any causal connection between the internal sensory experience and the external object of awareness. This sensory core is bereft of structure and remains ineffable; as such what the Buddhists identify as älambana or percept has no logical role in determining the propositional content of the 
judgement $[9 ; 10 ; 14]$. Matilal seeks to show that this view is not unconnected to the view of language that underpins this perspective. Dinnāga and many other Indian philosophers including Candrakīrti arrive at this view of cognition in accordance with their supposition that private language is possible. But Matilal refutes this view by using the argument especially of Quine and Wittgenstein that language is a social behavior. Wittgenstein's private language argument shows that the idea of language being private is unintelligible and thus to hold that private sensory experience cannot be expressed through language is equally unintelligible and logically incoherent. This is the reason why Buddhist critique of language, as Matilal claims, turns into a lingophobia that reduces mentalese entities to merely mythical or illusory projections. The Nyāya view, on the other hand, claims that any cognitive experience must be expressible in language. Gangeśa rules out the presence of the ineffable sensory core to be the essence of cognition on the ground that it is merely physical and is thus non-cognitive. Matilal interprets this to be a version of metaphysical realism, which argues for an inseparable connection between language and cognition: it is a linguistically compromised doctrine of knowing [6].

\section{Dharma}

While philosophers of India very seldom discussed moral philosophy, tradition - as for example represented in the Dharmaśāstra texts — they were quite conscious about issues of moral values, moral conflicts, and dilemmas, as also the difficulties of "practical reason" [4. P. 21]. In his essays on Indian ethics and justice, Matilal underscored the rational predilection in the deliberations, drawing in tandem from the Jaina theory of anekāntavāda ("not one-sided-ness") that reinforced his own vision of rational moral pluralism [15. P. 166]. The epics too exemplify a myriad of moral issues which are thought through rationally with the use of moral arguments. The irony is that Matilal reduced moral problems to basically moral dilemmas, when there could be straightforward moral challenges that are not presented to the agents as horns of a rational dilemma: for example, climate change and the dangers of the excessive use of fossil fuel, perhaps also premeditated war, murder and negligent manslaughter (say, from drunken driving), imperial ravages, and evaluative emotional responses to death, injustice, and malevolence [2]. Yet Matilal would state the problem in this form to argue that a rational solution is well-nigh imminent for any moral dilemma [16. P. 89].

Matilal was fond of narrating this account supposedly from the epics. Namely, the story around not telling a lie that in one of his earth-bound births had Kauśika reprimanded for causing the death of an innocent deer fleeing from its predator; while in a subsequent birth telling the lie in the recurrent situation to save the feeling deer cost him gravely the salvation he had all but earned through his stoical moral practices. This was his way of illustrating the tussle also between two dominant paradigms in Western ethical discourse, namely of utilitarianism and Kantian deontology. But overall, Matilal remained skeptical about the prospects of solid foundation for Indian ethics. Thus he averred: 
Certainly, there exists a lacuna in the tradition of Indian philosophy. Professional philosophers of India over the last two thousand years have been consistently concerned with the problems of logic and epistemology, metaphysics and soteriology, and sometimes they have made very important contributions to the global heritage of philosophy. But, except [for] some cursory comments and some insightful observations, the professional philosophers of India very seldom discussed what we call moral philosophy today. It is true that the dharmaśāstra texts were there to supplement the Hindu discussion of ethics, classification of virtues and vices, and enumeration of duties related to the social status of the individual. But morality was never discussed as such in these texts. On the other hand, the tradition was very selfconscious about moral values, moral conflicts and dilemmas, as well as about the difficulties of what we call practical reason or practical wisdom [4. P. 21].

Matilal nevertheless agonised over the exemplary moral dilemmas presented in narrative literature, particularly the epic Mahābhärata, and suggesting how there was always a rational solution around the corner or possibly missed, even by Krishna. Matilal was airing the suspicion that Indian philosophy, particularly during what he calls the Indian Middle Ages, did not break away sufficiently from preoccupations with theology and mysticism, and that the without 'logic' any branch philosophy is bound to flounder at its core. To that end he wrote a number of essays on Indian ethics, underscoring its supposed rational predilection, mostly in the context of the (Hindu) epics while also drawing from Jaina theory of anekāntavāda (not one-sided-ness) that reinforced Matilal's vision of moral pluralism. The epics embed and exemplify a myriad of moral issues which are thought through rationally; but the epics no more than the tradition at large, quite succeeded in articulation of a sui generis thesis that we would call 'ethics' or 'morality', without the cultural, theological and historical overtones and baggage that might go along with the disciplinary discourse [16]. The irony should not brush over any keen moral thinker that Matilal reduced moral problems and challenges to basically those presented in the context of moral dilemmas or conflicts, when in fact there may be straightforward moral challenges that are not presented to the agents as two horns of a dilemma or a conflict in search of a resolution: for example, climate change and the dangers of the excessive use of fossil fuel, perhaps also premeditated murder and negligent manslaughter (say, from drunken driving). Yet Matilal would state the problem in this form to underscore the point that a rational solution is well-neigh around the corner (or ought to be) for almost any moral dilemma. And so this is how he articulated his position:

Admission of moral conflicts or genuine moral dilemmas (or dharma-dilemmas) requires using some method toward making a rational choice. It is obvious that some sort of pre-ordering or ranking of principles helps such rational deliberation. In matters of ritual-orientated dharmas, when conflict arises, the Mīmāmsāa school has determined a fixed rule of pre-ordering, and has given a rational argument in favour of such ordering. Unfortunately, in all practical cases of value conflict or ordinary dharma-orientated conflict, it is extremely difficult to establish priorities in the same way. Many epic stories that illustrated 
such practical dharma-conflicts show that the practical resolution of such conflict does not always fix priorities according to the same pattern. It appears to me that this respect for the difficulties encountered in real life is not a mark of irrationality or inconsistency, but emphasizes that we sometimes face moral predicaments for which we cannot find a simply rational solution [16. P. 89].

Matilal returns us again and again to the epics where numerous instances of moral dilemmas appear to plague the actors, from the dice game that Yudhistira finds himself lured to (where the joint asset of the Pāndava brothers, including their shared Draupadī, is at stake and gambled away), to Arjuna's dilemma on the battlefield (to be in the fight, or not to be in the fight), and various conflicts that the paradigmatic hero of the Rāmāyana is also confronted with — such as whether to resist or accede to the decree of being sent to exile in the forest. Matilal claimed that "sometimes there was more realism in these old epic stories than they are given credit for today. They underlined the two most prominent aspects of dharma: the vulnerability of moral virtues and the ever-elusive nature of truth in the moral domain" [16. P. 99].

However, Matilal did believe that a historical understanding of the concept of dharma (he rarely strayed away from dharma to some of the other issues in Indian ethics, barring caste, karma and 'evil') — has some relevance today, for it remains a widely misunderstood concept in the modern study of Indian philosophy. And he concluded his insightful essay on 'Dharma and Rationality' by noting that the explanations of the traditional ethos of India has always been somewhat controversial among the Indianists (South Asianists) of today: "The sociologists or social anthropologists propagate one way of looking at it. The development economists favour another way of taking it. Both, however, assume that to understand modern India some basic knowledge of classical India is absolutely necessary" [16. P. 102]. And to that end, he proposed a comprehensive volume on Indian ethics, which has since been completed in which his own most celebrated essay in edited form on 'Dharma and Rationality' has been included (although he did not live to see the volume in print).

\section{"Evil" and suffering}

A belief commonly touted in modern times is that Indians had no cognisance of the ubiquitous problem of evil; some have extolled this as a virtue while others point to a certain defect or lacuna in Indian thinking. Matilal favored a different approach, arguing that, while the Buddhists and certain Hindus did use the argument from evil to undermine all possible theodicies, it is more pertinent to view evil in terms of suffering as the key "problem". Thus any attempt to conceptualise "evil" — whether metaphysical, natural, or moral — outside of this frame is fraught, for then one is trapped in justifying evil in the salvific designs or just play (Iîlā) of an external creator, a benevolent God, gods, or perhaps conjuring demons [15]. The theory is that suffering arises from an individual's own karma, or action-intentions and conduct, propelled often by prior-accumulated or past-life dispositions. Even the theistic Hindu schools, including early Nyāya theology, recognised the role 
played by karma in the existential facticity of suffering; a Supreme or Superintended Being, where accepted, might ameliorate and soften the burden of karma, but no agency can fully override the inexorable law of karma in the cause of justice $[17 ; 18]$.

\section{Ineffability}

The classical ineffability doctrine states that the Ultimate Reality or any deep mystical experience is not describable in words, that such wisdom (tattva) is beyond words: "wherefrom words turn back, along with the mind" (Taittiriya Upanisad 2.4.1); that is to say, whatever is the Ultimate is beyond the grasp of discursive thought and language. Matilal averred that a simplistic surrender to this silencing thesis would make a mockery of human beings' immense capacity for linguistic expression and use of symbolism, as well as the various logical tools that philosophers and theologians have at their disposal to create new modes of expression and unearth (aletheia) the vistas of hidden truths [19. P. 529]. This would include formulations that use paradoxes, contradictions, metaphors, figures of speech, even the via negativa and catuskoti (tretralemmas, as developed by the Buddhist dialectician Nāgārjuna), not to mention rhetoric and poetical language as also rhythmic meters or music, to impregnate the elusive truth with robust meaning, enchantment of the emotions, and aesthetic sensibility that would render the ineffable more readily accessible and explicable [15. P. 117-119; 20. P. 12-14].

Matilal indeed was a rare kind of thinker, a philosopher of profound sensibility who embodied East and West in balanced proportions and who demonstrated that Indian thought, even in its most metaphysical and soteriological or theological concerns $[14 ; 21]$, was rigorously analytical and logical as well as discursive [12]. His work has found broad endorsement and inspired lively debate not only among many contemporary Indian philosophers and Indologists, but also in international philosophical circles, including in Russia and neighbouring states.

\section{References}

[1] Garfield J et al, editors. Special Issue on 25th Anniversary of the Demise of Professor Bimal K. Matilal. Sophia. 2016;55(4):455-576.

[2] Bilimoria P. Three Dogmas of Matilal Direct Realism, Lingophilia, and Dharma Ethics. In: American Philosophical Association Newsletter. Asian and Asian-American Philosophers and Philosophies. 2017;17(1):11-14. URL: https://cdn.ymaws.com/www.apaonline.org/resource/collection/2EAF6689-4B0D4CCB-9DC6-FB926D8FF530/AsianV17n1.pdf

[3] 'Bimal K. Matilal'. In: Brown S, editor. The Dictionary of the Twentieth Century British Philosophers. Vol II. London/New York: Thoemmes Continuum; 2005. P. 665-667.

[4] Matilal BK. Moral Dilemmas: Insights from Indian Epics. In: Ganeri J, editor. Philosophy, Culture and Religion Collected Papers of B K Matilal. Vol. I. Ethics and Epics. Delhi: Oxford University Press; 2000.

[5] Matilal BK. The Logical Illumination of Indian Mysticism. Oxford: Clarendon Press; 1977. 
[6] Matilal BK. Perception: An Essay on Classical Indian Theories of Knowledge. Oxford, UK: Clarendon Press; 1986.

[7] Matilal BK, Chakrabarti A, editors. Knowing from Words - Western and Indian Philosophical Analysis of Understanding and Testimony. Dordrecht and Boston: Kluwer Academic; 1994.

[8] Bilimoria P. Śabdapramāṇa: World and Knowledge as Testimony in Indian Philosophy. New Delhi: DK Printworld; 2008. Revised edition from: Śabdapramāna: World and Knowledge. Studies of Classical India 10. Dordrecht: Kluwer/Springer; 1998.

[9] Ganeri J. Introduction. In: Ganeri J, editor. The Collected Essays of Bimal Krishna Matilal: Mind, Language and World. New Delhi: Oxford University Press; 2002. X-XXVI.

[10] Mohanty JN. Introduction to Relativism, Suffering and Beyond, Essays in Memory of Bimal K Matilal. New Delhi/New York: Oxford University Press. P. 10-11

[11] Bilimoria P. Review of Perception by Bimal K Matilal. Australasian Journal of Philosophy. March 1992;70(1):121-123.

[12] Matilal BK, Shaw JL, editors. Analytical Philosophy in Comparative Perspective: Exploratory Essays. Dordrecht: D. Reidel; 1985.

[13] Bilimoria P. Postcolonial Critique of Reason: Spivak Between Kant and Matilal. In: Bilimoria P, Al-Kassim D, editors. Postcolonial Reason and Its Critique. New Delhi: Oxford University Press; 2014. P. 1-12.

[14] Bilimoria P. Bimal Matilal's Navya-Realism, Buddhist 'Lingo-Phobia' and Mental Things. In: Prasad KS, editor. Language and Mind (Volume 2): The Classical Indian Perspective. New Delhi: Decent Books; 2008. P. 17-34.

[15] Matilal BK. The Problem of Evil. In: Matilal BK. Logical and Ethical Issues of Religious Belief. Calcutta: University of Calcutta; 1982. P. 23-41.

[16] Matilal BK. Dharma and Rationality. In: Bilimoria P, Prabhu J, Sharma R, editors. Indian Ethics, Volume I: Classical and Contemporary Challenges. Aldershot, UK: Ashgate/Routledge; (2007) 2017; Delhi: Oxford University Press; 2008. P. 79-102.

[17] Matilal BK. Logical and Ethical Issues of Religious Relief. Calcutta: University of Calcutta; 1978.

[18] Bilimoria P. Toward an Indian Theodicy. In: McBrayer JP, Howard-Snyder D, editors. The Blackwell Companion to the Problem of Evil. Oxford: Wiley Blackwell; 2013. P. $281-295$.

[19] Sarkar P. The Paradox of Ineffability: Matilal and Early Wittgenstein. Sophia, special issue. 2016;55(4):527-542. https://doi.org/10.1007/s11841-016-0543-z.

[20] Matilal BK. Philosophy, Culture and Religion: The Collected Essays of Bimal Krishna Matilal, Volume I: Mind, Language and the World. Delhi: Oxford University Press; 2002.

[21] Phillips S. Counter Matilal's Bias: The Philosophically Respectable. In: Chakrabarti A, editor. Indian Spiritual Thought. Studies in Humanities and Social Sciences. 1996; III (2): $173-183$.

\section{About the author:}

Bilimoria Purushottama - PhD, Principal Research Fellow, School of Historical and Philosophical Studies, University of Melbourne, Victoria, Australia; Head of Laboratory, Center for the Study of Indian Philosophy and Culture, RUDN University, Russia (e-mail: p.bilimoria@unimelb.edu.au). 


\title{
Философия Бимала К. Матилала: язык, реализм, дхарма и невыразимость
}

\section{Пурушоттама Билимориа}

Мельбурнский университет,

Школа исторических и философских исследований, Australia, 3010, Victoria, West Wing, Arts West (Building 148B),

Российский университет дружбы народов, Российская Федерация, 117198, Москва, Миклухо-Маклая, 6, p.bilimoria@unimelb.edu.au

\begin{abstract}
Аннотация. Предметом рассмотрения выступают теоретические и практические следствия так называемой «мягкой» версии эпистемологического реализма в философском проекте Бимала К. Матилала. Автор предлагает аналитический подход к интерпретации философии Матилала, что позволяет понимать ее в более широком контексте и сравнивать высказанные им аргументы о восприятии и объективности аргументы с современными аргументами в западной аналитической философии. Матилал может быть рассмотрен не только как продолжатель интеллектуальной традиции ньяя-вайшешика, но также и как сторонник реалистического подхода к трактовке языка вслед за Л. Витгенштейном, У. Куайном, Х. Патнэмом и М. Даммиттом. Несмотря на возможный эклектизм подобных воззрений, тем не менее именно такая стратегия позволяет ему стать воспреемником обеих аргументативных стратегий: критический пересмотр вопроса о невозможности приватного языка имел место и в западной, и в индийской философии, и сравнение этих подходов приводит нас в область социальной эпистемологии. Во второй части статьи рассмотрены этические аргументы об уязвимости моральных добродетелей, а также место концепта дхармы в моральной философии. Обращение к поэтическому и метафорическому языку представляется плодотворным шагом для обнаружения невыразимого, в том числе, посредством отрицания и чатускоти (тетралеммы), что продемонстрировано Матилалом на примере неприемлемости лжи. Невыразимость этического и ее взаимосвязь с практической мудростью, описанные Матилалом, играют ключевую роль в его интерпретации текстов Дхармашастры.
\end{abstract}

Ключевые слова: Бимал К. Матилал, индийская логика, ньяя-реализм, дхарма, моральная дилемма, теодицея и зло, концепция невыразимости

Информация о финансировании и благодарности. Работа подготовлена в рамках Соглашения между Министерством образования и науки РФ и Российским университетом дружбы народов № 075-15-2021-603 по теме: «Разработка методологии и интеллектуальной базы нового поколения по изучению индийской философии в ее соотношении с другими ведущими философскими традициями Евразии»

\section{История статьи:}

Статья поступила 15.12.2020

Статья принята к публикации 20.01.2021

Для цитирования: Bilimoria P. Bimal K. Matilal's Philosophy: Language, Realism, Dharma, and Ineffability // Вестник Российского университета дружбы народов. Серия: Философия. 2021. Т. 25. № 2. С. 250-259. DOI: 10.22363/2313-2302-2021-25-2-250-259

\section{Сведения об авторе:}

Билимория Пурушоттама - $\mathrm{PhD}$, профессор, Школа исторических и философских исследований, Мельбурнский университет, Австралия; руководитель лаборатории, Центр изучения индийской философии и культуры, Российский университет дружбы народов, Москва, Россия (e-mail: p.bilimoria@unimelb.edu.au). 